\title{
Evaluating the effectiveness of a preservice teacher technology training module incorporating SQD strategies
}

\author{
Yu-Yin Hsu ${ }^{1}$ and Chin-Hsi Lin ${ }^{2 *}$
}

\author{
* Correspondence: chinhsi@hku.hk \\ ${ }^{2}$ The University of Hong Kong, \\ Room 615, Meng Wah Building, \\ Pokfulam Road, Pokfulam, Hong \\ Kong \\ Full list of author information is \\ available at the end of the article
}

\begin{abstract}
Preparation to use information and communication technology (ICT) is an important component of preservice language teachers' training, and various existing teacher training models propose a range of strategies for increasing their technology knowledge and technology adoption rates. However, the relative effectiveness of these strategies remains unclear. Based on Tondeur et al.'s (2012) Synthesis of Qualitative Data model, which delineates the six main teacher preparation strategies (i.e., role modeling, reflection, instructional design, collaboration, authentic experience, and continuous feedback), the present study designed a 4 week training module for preservice language teachers and examined how these training strategies affected 63 participants' perceived technology knowledge and attitudes toward technology adoption. Among the six training strategies, reflection and instructional design had the highest positive impacts on these preservice teachers' self-reported knowledge about and attitudes towards using ICT. As well as revealing the relative impacts of each training strategy, the results indicate that our designed training module has considerable potential for application to teacher training in other subjects.
\end{abstract}

Keywords: Teacher education, ICT, Technology knowledge, TPACK, Technology adoption

Information and communication technology (ICT) has considerable potential for promoting second-language (L2) learning (e.g., Hsu, 2016; Lin, 2015). For this reason, ICT has emerged as a major component of language teacher education programs in the United States (Oxford \& Jung, 2007), Mainland China (Lin et al., 2017) and Hong Kong (Hong Kong Education Bureau, 2014), as well as of international professional standards in this field (e.g., International Society for Technology in Education (ISTE), 2012). However, while teachers around the world are becoming more familiar with ICT (European Commission, 2013; Fraillon, Ainley, Schulz, Friedman, \& Gebhardt, 2014), language teachers' knowledge of it, and of its application in L2 teaching, remain limited (Kim, 2011). As such, it has been noticed that more research on both how the training of preservice language teachers can increase their ICT adoption (Bustamante \& Moeller, 2013), and on how language teacher training can effectively develop knowledge of ICT use (Kissau, 2015; Schmid and Hegelheimer, 2014, b), is urgently needed.

(c) The Author(s). 2020 Open Access This article is licensed under a Creative Commons Attribution 4.0 International License, which permits use, sharing, adaptation, distribution and reproduction in any medium or format, as long as you give appropriate credit to the original author(s) and the source, provide a link to the Creative Commons licence, and indicate if changes were made. The images or other third party material in this article are included in the article's Creative Commons licence, unless indicated otherwise in a credit line to the material. If material is not included in the article's Creative Commons licence and your intended use is not permitted by statutory regulation or exceeds the permitted use, you will need to obtain permission directly from the copyright holder. To view a copy of this licence, visit http://creativecommons.org/licenses/by/4.0/. 
There are two main strands of research on language teacher education. The first uses technology adoption models to identify factors that may predict the uptake of ICT among educators (e.g., Lin et al., 2017), while the second focuses on the provision of ICT training within language teacher education programs, and testing its effects on the development of teacher knowledge (Chao, 2015; Cheng, 2014, 2017; Tai, 2015). While the number of studies of language teacher education has increased in recent decades, several research gaps remain. First, many studies that have proposed new training methods lack clear descriptions of their pedagogical designs (e.g., Cheng, 2014), making it difficult to replicate and evaluate the effectiveness of such methods. Second, the evaluation of ICT interventions in language teacher training has primarily focused on the growth of specific types of technology knowledge among preservice teachers (e.g., Cheng, 2017), rather than on their attitudes towards technology or their intentions to use it. And third, a lack of evaluation models for language teacher training has made it difficult to assess the impact of such ICT training.

Accordingly, this study designed a training module specifically for use in a teacher education program for preservice teachers of the Chinese language (described in detail below, in the section Rationale and Design of the ICT Training Module). A pretest and a posttest were used to determine, first, the effect of its implementation on such teachers' perceived technology knowledge and attitudes toward technology adoption, and second, which of its six training strategies worked the best. The module's design was rooted in Tondeur et al. (2012) Synthesis of Qualitative Data model (SQD-model): an evidence-based teacher training model that divides teacher education programs' technology integration components into six main types (see below, under ICT Training in Language Teacher Education), and measures preservice teachers' perceptions of each of them via a self report instrument called the SQD-scale. This scale has been found capable of providing informative evaluations of teacher education programs in general (e.g., Baran et al., 2017; Tondeur et al., 2018), but has not yet been widely studied in the context of L2 teaching - a gap that the current study helps to fill. In addition to the SQD-scale, for more comprehensive evaluation of the training module in particular, we utilized an instrument designed to measure the respondents' attitudes toward practical use of their technological pedagogical content knowledge (TPACK; see Mishra \& Koehler, 2006) that was developed by Yeh et al. (2014) (i.e., the TPACK-practical scale; see Design and Rationale, below). To measure our training's impact on technology acceptance, we used the scales in Teo's (2011) study.

Language teacher education programs undoubtedly play major roles in equipping teachers with the knowledge and skills they need to use ICT in the classroom (b). The next section reviews three key themes of the relevant prior literature. They are: ICT training in language teacher education; such training's effects on preservice language teachers' knowledge; and its effects on such teachers' technology adoption.

\section{Integrating technology into language teacher education ICT training in language teacher education}

While many previous studies have emphasized the importance of preparing preservice teachers to use technology in their teaching, few have focused on how to effectively promote their knowledge and use of it (Baran et al., 2017). In the specific case of language 
teacher education, research of the latter type is especially sparse (Lin et al., 2017; for a review, see also Hong, 2010). Therefore, it remains unclear whether specific strategies within training models are actually being implemented, or - if they are - whether such strategies actually affect preservice teachers' ICT attitudes, competence, or knowledge (Tondeur et al., 2018).

Meanwhile, several studies have independently reported on certain training strategies that could foster language teachers' ICT skills for teaching, such as allowing them to learn ICT-integrated language teaching by doing (Schmid and Hegelheimer, 2014, b; Tai, 2015); situating ICT training in authentic teaching and planning contexts that feature peer collaboration (Reinders \& Hubbard, 2012; Schmid and Hegelheimer, 2014, b); and teaching specific ways that ICT can be used in language teaching, rather than simply teaching the technology (Lin et al., 2017). These strategies partially overlap with the six core strategies included in the SQD-model, i.e., role modeling; reflection on the role of technology; learning technology by design; collaborating with peers; authentic technology experience; and continuous feedback. Therefore, those six strategies were incorporated into our proposed ICT training module, and the SQD-scale was adopted to provide a more holistic measure of their training's effects.

\section{Effects of language teacher training on TPACK}

As well as laying the theoretical and practical groundwork for a detailed investigation of pedagogical applications of ICT in language teaching (Baser et al., 2016; Yeh et al., 2014), TPACK has the potential to clarify the relationship between, on the one hand, the strategies adopted by teacher training programs, and on the other, preservice language teachers' intentional use of technology for educational purposes in their own teaching (for a review, see Lin et al., 2017).

Mouza et al., (2014) proposed that TPACK theories be integrated with pedagogical approaches and experiences. Based on their model, several subsequent studies have argued that language teacher education must integrate theories with experience if it is effectively to promote the competent use of ICT in language teaching (Liu, 2017; Liu \& Kleinsasser, 2015). It should also be noted that the integrative approach proposed by the aforementioned studies utilized three of the six strategies from Tondeur et al.'s (2012) SQD-model, i.e., role models, reflection, and learning technology by design; but the question of which training strategies are most helpful to the development of specific TPACK components remains unanswered (cf. Kessler, 2016).

\section{Effects of language teacher training on technology adoption}

Prior research has found that language teachers' positive perceptions and levels of knowledge of ICT's educational applications were both positively correlated with the degree of technology integration in their future classrooms (Lam, 2000). The quality and quantity of the technology use experience provided in teacher education programs have both been found to be positively correlated with preservice teachers' eventual adoption of technology (Author, 2017; Cheng, 2017); and the importance of such effects are also implicit in the SQD-model (Tondeur et al., 2012). Similarly, increases in hands on, authentic experience have been shown to help preservice language teachers to become more confident about designing curricula integrating ICT (e.g., Bustamante 
\& Moeller, 2013; Tai, 2015) and to achieve clearer understandings of the pedagogical associations among theories, technology applications, and teaching activities (Baser et al., 2016; Kissau, 2015).

\section{Rationale and design of the ICT training module Description of the course}

The course in which our 4 week ICT training intervention was implemented ran for all 12 weeks of the first semester of a master's program in teaching Chinese as a foreign language in Hong Kong in 2017. It consisted of three modules: pedagogical theories and instructional design; linguistic aspects of the teaching of Chinese as a foreign language; and ICT training. Assessments were conducted upon students' completion of each module, and a fourth assessment covering the whole course was conducted at the end of the semester. Our experimental ICT training module, which was identical to the third phase of the course described above, consisted of four three-hour sessions, i.e., one session in each of weeks 9 through 12 .

\section{Design rationale}

Before designing the ICT training module, the authors identified four key issues involving technology in language teacher education courses (for a review, see Angus, 2017). The first was a lack of competence and confidence, leading to low levels of technology adoption after training; the second, a disproportionate focus on older technology such as Web 1.0 tools; the third, the use of tutorials, readings, and lectures to teach about technology, rather than learning with technology itself; and the fourth, lack of handson experience, and too few reflective discussions about technology. To address these issues, the authors' development of their ICT training module utilized Mouza et al.'s (2014) integrative method, the SQD-model, and literature specifically relevant to language teacher education. The integrative approach, which implies learning through technology rather than merely about it, was selected as having the potential to address issues one, three, and four. Issue two was addressed through learning technology by design: a process whereby preservice teachers solve language teaching problems with technology (for examples, see Koehler \& Mishra, 2005). It should also be noted here that our ICT training module contained little direct instruction in the use of any specific technological tool.

\section{Design of the ICT training module}

When designing the training module, our goals were that it would facilitate the development of preservice language teachers' ICT confidence and competence while addressing the training issues reported in the literature. The module's design is illustrated in Fig. 1.

In keeping with learning technology by design, each session commenced with an illdefined problem related to designing a technology enhanced language learning lesson. This was followed by a short group discussion of possible ways technology could solve it. The instructor then presented a personal example or an award winning role model from practitioners. The first topic, for example, asked the students how they would teach grammar without being boring or using worksheets. The instructor presented two examples: 


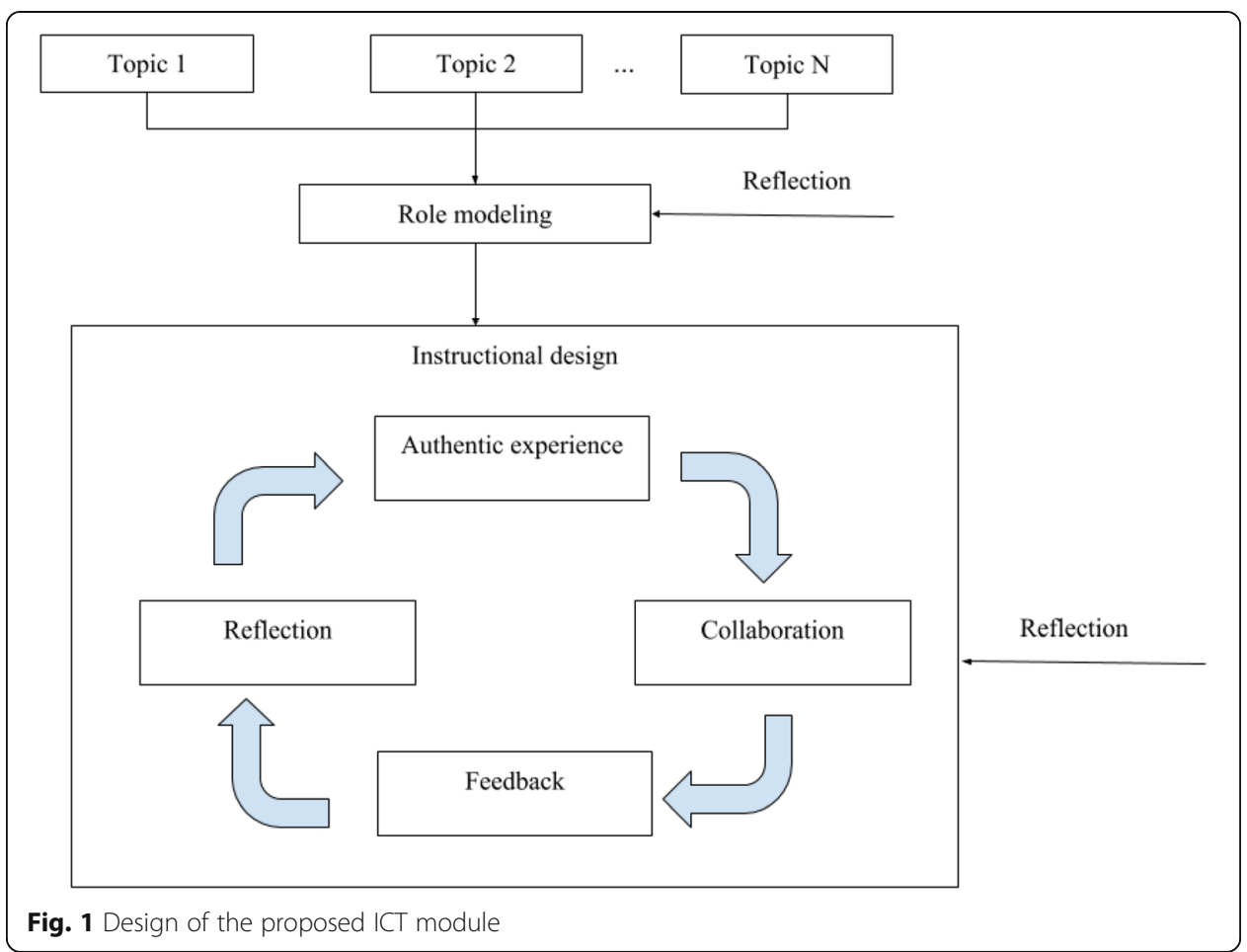

one that sought to engage learners using Kahoot, a game based online platform, as a formative assessment tool, and another that used ToonDoo and GoAnimate to create a virtual character and advocate for him/her in a contest where the students voted for the smartest character. During the competition process, students would use the target adjectival clauses naturally. After the demonstration, the class reflected on technology and pedagogy, and discussed the relevant technology's potential benefits and pitfalls.

After reflecting on the examples, the students were divided into small groups, each of which was asked to create a technology enhanced activity related to the discussion topic. The instructor did not prescribe any technological tools or pedagogical approaches. Instead, each group decided how to tackle the issue and what technological tools might be most appropriate to their teaching methods. The instructional design activity incorporated four of the SQD-model's six training strategies, i.e., reflection, collaboration, authentic experience, and feedback. Reflection and feedback at this stage occurred spontaneously within each group. At the end of the instructional design task, each group presented its design and received feedback on it from other groups before reflecting on how to further improve its technology enhanced activities.

Our study of the teacher training module described above was guided by the following research questions:

1. What support and training strategies did the preservice Chinese language teachers perceive as being provided by the ICT training module?

2. Was the ICT training these teachers received associated with change in their TPACK, and if so, what were the relative contributions of its various training strategies to such change? 
3. Did the ICT training these teachers received change their attitudes toward technology and/or their intention to use technology in their teaching? If so, what were the relative contributions of its various training strategies to such change?

\section{Methods}

Adopting a pretest/posttest format, we studied three phenomena. These were the effect of each training strategy, as revealed by SQD-scale data; the training's impact on the participant teachers' TPACK-practical knowledge (Yeh et al., 2014); and the training's impact on technology acceptance, as measured by Teo's (2011) scales. Open-ended survey questions were also included to supplement the findings derived from the Likert scaled instruments.

\section{Participants}

Using convenience sampling, the authors recruited seven male and 56 female first-year master's students in teaching Chinese as a foreign language, all aged 20-25 and all enrolled in the same teaching-methods course. The pretest and posttest were administered before and after the ICT module, respectively. All 63 participants completed the former, and all but three completed the latter, a response rate of $95 \%$.

\section{Data sources and measures}

The pretest incorporated the 21 item TPACK-practical scale, 16 items from the technology acceptance model, and background information, but not the SQD-scale. It also asked the participants to indicate their previous experience of ICT tools for Chinese language teaching. In addition to the pretest's questions covering the technology acceptance model and TPACK, the posttest included the 34 items of the SQD-scale to assess the participants' perceptions of the support they had been given by the teacher training program, and what they had learned about ICT applications.

Apart from the background information questions and two open ended questions (one about the ICT tools the participants had been using, and the other about their attitudes toward the training), all items were answered on the same Likert scale, ranging from $1=$ not at all true of me to $5=$ very true of $m e$. The survey language was Chinese. All its items were translated into Chinese by a professor of education; another then translated the Chinese version back into English to confirm that its meaning had not been altered by the translation (see below under Availability of data and materials for the full list of items in the pretest and the posttest).

\section{SQD-scale}

The Chinese version of the SQD-scale covered the six SQD training strategies (see Table 1). Cronbach's alpha testing revealed that the scale as a whole had a high internal consistency, .96, while the equivalent values for its six subscales ranged from .81 to .95.

\section{Perceived TPACK}

The TPACK-practical scale, adopted from Yeh et al. (2014), was used to assess the participants' perceived TPACK. The Cronbach's alpha values of the eight subdimensions in the pretest and posttest are shown in Table 2, along with sample questions. 
Table 1 SQD-scale Sample Items

\begin{tabular}{ll}
\hline Factor & Sample item \\
\hline Role modeling & "I saw many examples of ICT use in an educational setting" \\
Reflection & "We discussed the challenges of integrating ICT into education" \\
Instructional design & "I received sufficient help in designing lessons that incorporated ICT" \\
Collaboration & "Students helped each other to use ICT in an educational context" \\
Authentic experience & "I was encouraged to gain experience of using ICT in a classroom setting" \\
Feedback & "I received sufficient feedback on the use of ICT in my lessons" \\
\hline
\end{tabular}

The technology acceptance model, adopted from Teo (2011), consisted of subjective norms (SU), perceived usefulness of ICT (PU), ease of use of ICT (EU), and intention to use ICT in teaching (IU). Each of these dimensions is discussed in turn below.

\section{Subjective norms}

SU was measured by two items, one of which was People who are important to me at work think I should use ICT. The Cronbach's alpha values for SU on the pretest and posttest were .98 and .96 , respectively.

\section{Perceived usefulness}

One example of the five survey items for PU was, Using ICT will enhance my language teaching effectiveness. Its Cronbach's alphas for the pretest and posttest were .88 and .89 , respectively.

\section{Ease of use}

One sample survey item from among the six used to measure EU was I think it is easy to use ICT. Its Cronbach's alphas were .93 for the pretest and .94 for the posttest.

Table 2 TPACK-practical Scale Sample Items

\begin{tabular}{|c|c|c|c|}
\hline \multirow[t]{2}{*}{ Factor } & \multicolumn{2}{|c|}{$\begin{array}{l}\text { Cronbach's } \\
\text { alpha }\end{array}$} & \multirow[t]{2}{*}{ Sample item } \\
\hline & Pretest & Posttest & \\
\hline $\begin{array}{l}\text { Using ICT to understand } \\
\text { students }\end{array}$ & .90 & .91 & "I know how to use ICT to understand students" \\
\hline $\begin{array}{l}\text { Using ICT to understand } \\
\text { subject content }\end{array}$ & .88 & .91 & $\begin{array}{l}\text { "We discussed the challenges of integrating ICT in } \\
\text { education" }\end{array}$ \\
\hline Planning ICT-infused curricula & .93 & .93 & "I am able to design technology-infused lessons or curricula" \\
\hline $\begin{array}{l}\text { Using ICT representations to } \\
\text { present materials }\end{array}$ & .92 & .95 & "I am able to select appropriate ICT representations" \\
\hline $\begin{array}{l}\text { Using ICT-integrated teaching } \\
\text { strategies }\end{array}$ & .87 & .89 & $\begin{array}{l}\text { "I am able to apply appropriate teaching strategies in } \\
\text { technology-integrated instruction" }\end{array}$ \\
\hline $\begin{array}{l}\text { Applying ICT to instructional } \\
\text { management }\end{array}$ & .86 & .84 & $\begin{array}{l}\text { "I am able to describe ICT's advantages and disadvantages } \\
\text { for instructional management" }\end{array}$ \\
\hline $\begin{array}{l}\text { Infusing ICT into teaching } \\
\text { contexts }\end{array}$ & .91 & .93 & $\begin{array}{l}\text { "I am able to use ICT to facilitate the achievement of } \\
\text { teaching objectives" }\end{array}$ \\
\hline Using ICT to assess students & .90 & .89 & $\begin{array}{l}\text { "I know the types of technology-infused assessment } \\
\text { approaches" }\end{array}$ \\
\hline TPACK-practical, overall & .97 & .98 & N/A \\
\hline
\end{tabular}


Intention to use ICT in teaching

IU was measured by three items, one of which was I look forward to using ICT in language teaching. This factor's Cronbach's alphas for the pretest and posttest were .96 and .97 .

\section{Data analysis}

Both quantitative and qualitative data were used to answer each of the research questions. In terms of quantitative data, to answer RQ1, descriptive statistics were calculated to highlight the participants' perceptions of each training model. To answer RQ2, paired samples $t$ tests were performed to establish whether there were significant differences between the participants' pretest and posttest responses. The sample size was larger than 30, the minimal sample size for a paired sample $t$ test.

To answer RQ3, multiple regression was performed, with perceived changes in the respondents' knowledge and skills as the dependent variables, and specific training components as the independent ones. Our final sample size of 60 was larger than the absolute minimum of 10 observations per predictor in multiple regression recommended by VanVoorhis and Morgan (2007). On the qualitative side, answers to the two open ended survey questions were coded and analyzed using thematic analysis (Braun \& Clarke, 2006; Miles \& Huberman, 1994), a widely used method of inductively identifying common themes within such data.

\section{Results}

\section{Perceptions of the ICT training model}

To better understand the participants' perceptions of the ICT training they received (RQ1), means, standard deviations, and Pearson correlations among the SQD-model's strategies and its subscales were calculated (see Table 3). The participants had generally positive attitudes toward all six of those strategies, with authentic experience receiving the highest score $(\mathrm{M}=3.90, S D=0.80 ; 79.4 \%$ agreed $)$ and reflection the second highest $(\mathrm{M}=3.86, S D=0.71 ; 80.9 \%$ agreed). Their responses to the open-ended questions also suggested that the ICT training model was well received, as prompting good discussions, providing multiple forms of feedback and opportunities to reflect, and inspiring them to go beyond traditional teacher centered methods. One wrote "the training is very helpful for teachers to learn how to better design the curriculum and to incorporate more creative methods in teaching the content knowledge." Four participants

Table 3 Descriptive Statistics and Correlations among SQD and Its Subscales

\begin{tabular}{llllllllll}
\hline Scale & Mean & SD & 1 & 2 & 3 & 4 & 5 & 6 & SQD \\
\hline 1. ROL & 3.76 & .75 & 1 & - & - & - & - & - & - \\
2. REF & 3.86 & .71 & $.819^{* * *}$ & 1 & - & - & - & - & - \\
3. DES & 3.73 & .70 & $.750^{* * *}$ & $.821^{* * *}$ & 1 & - & - & - & - \\
4. COL & 3.76 & .75 & $.721^{* * *}$ & $.793^{* * *}$ & $.842^{* * *}$ & 1 & - & - & - \\
5. AUT & 3.90 & .80 & $.752^{* * *}$ & $.808^{* * *}$ & $.852^{* * *}$ & $.850^{* * *}$ & 1 & - & - \\
6. FEE & 3.58 & .84 & $.694^{* * *}$ & $.740^{* * *}$ & $.793^{* * *}$ & $.759^{* * *}$ & $.786^{* * *}$ & 1 & - \\
SQD & 3.77 & .69 & $.869^{* * *}$ & $.913^{* * *}$ & $.928^{* * *}$ & $.913^{* * *}$ & $.930^{* * *}$ & $.883^{* * *}$ & 1 \\
\hline
\end{tabular}

Note: ROL Role modeling, REF Reflection, DES Instructional design, COL Collaboration, AUT Authentic experience, FEE Feedback; *** $p<.001$ 
indicated that demonstrations of technology use to address a pedagogical issue were also inspiring, with one saying: "watching other groups' presentations expanded my thoughts about using technology tools in my teaching, and I learned which tools can be used to meet my pedagogical goals."

\section{Perceived training effects on TPACK-practical}

With respect to whether and how training strategies changed trainees' TPACK (RQ2), our results presented in Table 4 show that the participants' overall TPACK-practical before the training was slightly above neutral $(\mathrm{M}=3.13, S D=0.84 ; 59.1 \%$ agreed), indicating that they had some basic knowledge of using ICT in Chinese language education. Among the same instrument's eight subscales, the participants' two highest pretest scores were for using ICT to present materials $(\mathrm{M}=3.29, S D=1.07 ; 40.9 \%$ agreed $)$ and planning ICT infused curricula $(M=3.20, S D=0.84 ; 57.6 \%$ agreed). Their lowest was for using ICT to assess students $(\mathrm{M}=2.99, S D=1.00 ; 33.3 \%$ agreed $)$.

After the training, overall TPACK-practical reached 3.66 ( $S D=0.74 ; 77.8 \%$ agreed), and among the subscales, the pattern was similar to the pretest, in that using ICT to present materials received the highest score $(\mathrm{M}=3.81, S D=0.85 ; 71.4 \%$ agreed $)$ and using ICT for assessment the lowest ( $M=3.53, S D=0.87 ; 57.1 \%$ agreed). Paired samples $t$ tests revealed that, after the ICT training, overall scores for TPACK-practical increased significantly, $t(62)=4.08, p=0.0001$. All eight subscales also showed significant increases, ranging from .47 to .57 points ( $\beta$ ranged from 0.50 to 0.67 ).

Answers to the first open ended question revealed that the participants had used seven major categories of technological tools before the training, the top three being multimedia resources (e.g., videos/YouTube, music, Flash, ebooks, email, and pictures; 62 students), PowerPoint/Prezi (41 students), and computer peripherals and smart devices (e.g., computers, recorders, iPads, and cell phones; 27 students). Among the other four such categories, only online games (e.g., Kahoot and Quizlet; seven students) were mentioned by more than $10 \%$ of the sample. After the training, PowerPoint was cited by all participants, but the proportion who mentioned other typical information carriers such as cell phones and tablets had gone down. There was a rise in the number who said they had used more interactive/engaging tools, including some that had not been

Table 4 Descriptive Statistics and t-test Results for TPACK-practical and Its Subscales

\begin{tabular}{|c|c|c|c|c|c|c|c|}
\hline \multirow[t]{2}{*}{ Factors } & \multicolumn{2}{|c|}{ Pre-training } & \multicolumn{2}{|c|}{ Post-training } & \multirow[t]{2}{*}{$t$-test } & \multirow[t]{2}{*}{ n } & \multirow[t]{2}{*}{$\overline{E S}$} \\
\hline & Mean & $S D$ & Mean & $S D$ & & & \\
\hline Using ICT to understand students & 3.08 & .84 & 3.61 & .77 & -4.42 & $<.0001$ & .66 \\
\hline Using ICT to understand subject content & 3.13 & .99 & 3.58 & .78 & -3.24 & .0019 & .50 \\
\hline Planning ICT-infused curricula & 3.20 & .84 & 3.76 & .84 & -3.96 & .0002 & .67 \\
\hline Using ICT representations to present materials & 3.29 & 1.07 & 3.81 & .85 & -3.07 & .0031 & .54 \\
\hline Using ICT-integrated teaching strategies & 3.09 & .95 & 3.63 & .77 & -3.49 & .0009 & .62 \\
\hline Applying ICT to instructional management & 3.11 & .92 & 3.68 & .81 & -3.89 & .0002 & .66 \\
\hline Infusing ICT into teaching contexts & 3.14 & .96 & 3.71 & .85 & -3.79 & .0003 & .63 \\
\hline Using ICT to assess students & 2.99 & 1.00 & 3.53 & .87 & -3.47 & .001 & .58 \\
\hline TPACK-practical & 3.13 & .84 & 3.66 & .74 & -4.08 & .0001 & .67 \\
\hline
\end{tabular}

Note: ${ }^{* *} p<.01,{ }^{* * *} p<.001$; Effect sizes were calculated using Cohen's D 
included in the training module (e.g., iMovie, BookCreator, and EducaPlay). The participants also reported increases in TPACK, and their reasons for choosing specific technology tools included wanting to create "a more student centered classroom", to foster an "interactive learning environment" and/or "to engage and motivate students."

To further explore the effects of the module's specific ICT training strategies on gains in TPACK-practical and its subscales, nine multiple regressions were performed, with the dependent variable being such gains, and the independent variables being the SQDmodel's strategies (see Table 5). Only two coefficients were statistically significant. Role modeling had a significantly negative effect on applying ICT to instructional management ( $\beta=-0.47, p=0.03$ ); and reflection had a significantly positive effect on infusing ICT into teaching contexts $(\beta=0.59, p=0.027)$.

\section{Perceived training effect on technology adoption}

Next, descriptive statistics were calculated to examine whether our proposed SQDtraining module altered the trainees' overall approach to technology adoption: i.e., specifically, whether it was perceived as contributing to changes in their attitudes to ICT, and whether specific training strategies were likely to impact their ICT adoption (RQ3). Before training, as shown in Table 6, the participants' SU was above neutral ( $M=3.46$, $S D=0.93 ; 56.1 \%$ agreed), indicating that they felt technology use in their Chinese language teaching was expected; and their PU and EU were respectively $3.58(S D=0.75$; $72.7 \%$ agreed) and $3.39(S D=0.78 ; 69.7 \%$ agreed), reflecting their perceptions that using technology in their teaching would be both easy and useful.

After training, all these scores increased - significantly, for $\mathrm{SU}(\mathrm{M}=3.82, S D=1.00, t$ $[62]=2.48, p=0.016), \mathrm{PU}(\mathrm{M}=3.86, S D=0.74, t[62]=2.55, p=0.013)$, and $\mathrm{EU}(\mathrm{M}=$ $3.39, S D=0.78, t[62]=2.58, p=0.012)$ - and the effect sizes ranged from 0.33 to 0.37 . The score for IU increased, but not significantly $(\mathrm{M}=4.28, S D=0.79,84.1 \%$ agreed, $t$

Table 5 Effect Sizes of SQD-training Strategies on TPACK-practical

\begin{tabular}{llllllllll}
\hline & 1 & 2 & 3 & 4 & 5 & 6 & 7 & 8 & 9 \\
\hline Role modeling & -0.40 & -0.27 & -0.29 & -0.36 & -0.36 & $-0.47^{*}$ & -0.39 & -0.40 & -0.40 \\
& $(-1.85)$ & $(-1.24)$ & $(-1.34)$ & $(-1.63)$ & $(-1.64)$ & $(-2.23)$ & $(-1.78)$ & $(-1.80)$ & $(-1.87)$ \\
Reflection & 0.50 & 0.46 & 0.48 & 0.28 & 0.27 & 0.47 & $0.59^{*}$ & 0.28 & 0.48 \\
& $(1.95)$ & $(1.78)$ & $(1.87)$ & $(1.08)$ & $(1.05)$ & $(1.87)$ & $(2.28)$ & $(1.07)$ & $(1.87)$ \\
Instructional design & 0.02 & -0.45 & -0.40 & -0.42 & -0.52 & -0.47 & -0.25 & 0.08 & -0.33 \\
& $(0.08)$ & $(-1.61)$ & $(-1.43)$ & $(-1.50)$ & $(-1.90)$ & $(-1.77)$ & $(-0.88)$ & $(0.27)$ & $(-1.22)$ \\
Collaboration & 0.10 & 0.26 & -0.04 & 0.21 & 0.23 & 0.16 & -0.02 & 0.14 & 0.14 \\
& $(0.39)$ & $(1.02)$ & $(-0.14)$ & $(0.83)$ & $(0.90)$ & $(0.64)$ & $(-0.07)$ & $(0.53)$ & $(0.53)$ \\
Authentic experience & 0.26 & 0.28 & 0.55 & 0.46 & 0.48 & 0.47 & 0.35 & 0.13 & 0.41 \\
& $(0.94)$ & $(1.01)$ & $(1.99)$ & $(1.68)$ & $(1.77)$ & $(1.77)$ & $(1.26)$ & $(0.45)$ & $(1.52)$ \\
Feedback & -0.15 & 0.04 & 0.01 & 0.12 & 0.20 & 0.16 & 0.01 & 0.09 & 0.06 \\
& $(-0.71)$ & $(0.18)$ & $(0.05)$ & $(0.58)$ & $(0.94)$ & $(0.79)$ & $(0.05)$ & $(0.41)$ & $(0.27)$ \\
Constant & $-1.31^{*}$ & -1.36 & -1.26 & -1.35 & -1.02 & -1.17 & -1.38 & -1.48 & -1.30 \\
& $(-2.01)$ & $(-1.78)$ & $(-1.62)$ & $(-1.45)$ & $(-1.21)$ & $(-1.49)$ & $(-1.63)$ & $(-1.68)$ & $(-1.83)$ \\
\hline
\end{tabular}

Note: $t$ statistics in parentheses; ${ }^{*} p<.05$; coefficients were standardized

1: Using ICT to understand students; 2: Using ICT to understand subject content; 3: Planning ICT-infused curricula; 4 : Using ICT representations to present materials; 5: Using ICT-integrated teaching strategies; 6: Applying ICT to instructional management; 7: Infusing ICT into teaching contexts; 8: Using ICT to assess students; 9: TPACK-practical 
Table 6 Descriptive Statistics and t-test Results for Technology-adoption Variables

\begin{tabular}{|c|c|c|c|c|c|c|c|}
\hline \multirow[t]{2}{*}{ Factors } & \multicolumn{2}{|c|}{ Pre-training } & \multicolumn{2}{|c|}{ Post-training } & \multirow{2}{*}{$\begin{array}{l}\text { t- } \\
\text { test }\end{array}$} & \multirow[t]{2}{*}{$p$} & \multirow[t]{2}{*}{ ES } \\
\hline & Mean & $S D$ & Mean & SD & & & \\
\hline SN & 3.46 & 0.93 & 3.82 & 1.00 & $2.48^{*}$ & .016 & .37 \\
\hline PU & 3.58 & 0.75 & 3.86 & 0.74 & $2.55^{*}$ & .0132 & .38 \\
\hline EU & 3.39 & 0.78 & 3.65 & 0.79 & $2.58^{*}$ & .0122 & .33 \\
\hline IU & 4.12 & 0.73 & 4.28 & 0.79 & 1.5 & .139 & .21 \\
\hline
\end{tabular}

$[62]=1.50, p=0.139)$, perhaps because it was quite high before the training $(\mathrm{M}=4.12$, $S D=0.73 ; 83.3 \%$ agreed).

Next, to assess each training component's separate influence on the participants' technology adoption, four multiple regression analyses were performed, with the dependent variables being gains in SU, PU, EU, and IU (see Table 7). Only one coefficient was statistically significant: instructional design's positive impact on IU ( $\beta=0.65$, $p=0.013)$.

The qualitative data indicated that most of the students thought language teachers should actively and selectively choose ICT tools to create more fun and engaging curricula, implying that their perceptions of the value of ICT tools had increased. One student mentioned that "the training has taught me how to select and use technology tools in the future for me to effectively achieve pedagogical goals." Another wrote, "the training and the activities in the class made me realize that I can do similar things in my future teaching [with ICT], and to enrich the content of my classes." The various types of pedagogical value that were mentioned as having been added by ICT tools included increasing students' learning motivation, and providing timely feedback. In addition, students reported how the training reshaped their pedagogical approaches.

Table 7 Effect Sizes of Training Components on Technology Adoption

\begin{tabular}{|c|c|c|c|c|}
\hline & SU & $\mathrm{PU}$ & EU & IU \\
\hline \multirow[t]{2}{*}{ Role modeling } & -0.04 & -0.08 & 0.00 & 0.18 \\
\hline & $(-0.18)$ & $(-0.38)$ & $(0.01)$ & $(0.92)$ \\
\hline \multirow[t]{2}{*}{ Reflection } & 0.50 & 0.18 & -0.07 & 0.01 \\
\hline & $(1.83)$ & $(0.69)$ & $(-0.26)$ & $(0.06)$ \\
\hline \multirow[t]{2}{*}{ Instructional design } & 0.01 & 0.01 & 0.18 & $0.65^{*}$ \\
\hline & $(0.04)$ & $(0.05)$ & $(0.66)$ & $(2.56)$ \\
\hline \multirow[t]{2}{*}{ Collaboration } & -0.16 & 0.40 & 0.10 & -0.12 \\
\hline & $(-0.58)$ & $(1.54)$ & $(0.41)$ & $(-0.50)$ \\
\hline \multirow[t]{2}{*}{ Authentic experience } & 0.00 & -0.05 & 0.34 & 0.15 \\
\hline & $(0.00)$ & $(-0.17)$ & $(1.26)$ & $(0.60)$ \\
\hline \multirow[t]{2}{*}{ Feedback } & -0.01 & -0.02 & -0.11 & -0.39 \\
\hline & $(-0.02)$ & $(-0.11)$ & $(-0.51)$ & $(-2.00)$ \\
\hline \multirow[t]{2}{*}{ Constant } & -1.64 & $-1.73^{* *}$ & $-1.65^{* *}$ & $-2.23^{* * *}$ \\
\hline & $(-1.99)$ & $(-2.83)$ & $(-2.96)$ & $(-4.33)$ \\
\hline
\end{tabular}


One wrote, "I have learned how to apply ICT tools in teaching; in the future, I can use more creative teaching methods beyond the traditional approach."

\section{Discussion}

\section{Attitudes toward ICT training}

The present study's 4 week ICT training module was well received, and the participants reported positive perceptions of the support and training provided by all six of the SQD-model's core strategies. Among those strategies, authentic experience was ranked the highest, followed by reflection. Continuous feedback received the lowest ratings, though these were still above neutral.

Authentic experience has been identified as a key component of both teacher education in general (see Tondeur et al., 2012) and language teacher education in particular (see, b). Though language teaching methods courses often provide some degree of authentic experience of technology use (Angus, 2017), recent research has suggested that ICT training in such contexts is often "inadequate, inappropriate, irrelevant, or outdated" (Kessler, 2018, p. 215). Such problems may be related to the two distinct modes in which technology is commonly deployed in language teacher education: learning about technology, vs. learning through technology (Angus, 2017). The former seeks to provide authentic experience via lectures, demonstrations of technology tools, and readings, while the latter attempts to do so using course management systems, blogs, and online discussions. Our training module was rooted in Koehler and Mishra's (2005) learning technology by design approach, and intentionally built around ill defined problems to facilitate the fusion - i.e., into TPACK - of the participants' previously unconnected or loosely connected knowledge about pedagogy, content, technology, and context. More specifically, the training provided opportunities for preservice language teachers to develop content specific technology practices that were tailored to both learners and contexts. Through a recursive design process, and continuous feedback both from the instructor and from peers within and beyond the group, the participants learned not only about technology and design, but also about their pedagogical purposes, and the nature of learning itself (Koehler \& Mishra, 2005).

Our results are also in line with those of previous studies that highlighted the importance of reflection in language teacher education involving ICT (Tearle \& Golder, 2008; Tondeur et al., 2012). Hands on practice of technology application, along with peer evaluation of teaching demonstrations that integrate ICT, prompted many of our participants to acknowledge that they had learned various types of technology tools for different teaching purposes, beyond the basic word/picture processing tools (e.g., PowerPoint) and video clips that they had hitherto used.

Interestingly, role modeling was ranked only third among the six components analyzed in our study, despite being widely considered one of the most important aspects of teacher education (e.g., Angeli \& Valanides, 2009; Haydn \& Barton, 2007; Laronde \& MacLeod, 2012; Tearle \& Golder, 2008). It is possible that these prior studies' participants lacked both knowledge of technology per se and knowledge of how to use it. If so, this could have engendered lack of confidence prior to the training they received, which in turn could explain why they placed so much emphasis on the role modeling provided by their instructors. Among the preservice teachers sampled in the current study, on the other hand, lack of 
basic knowledge was not a marked problem, and the intensive training they subsequently received could also have improved their ability to independently transfer TPACK to real world teaching contexts in ways that positively impacted their confidence and ability (cf. Dorner \& Kumar, 2016). In any case, our results do not indicate that the participants failed to value role modeling, but only that they valued it less than authenticity and reflection. Regarding the apparent negative effect of role modeling on the use of ICT for instructional management, it should be noted that although we carefully prepared teaching materials for role modeling, we mainly focused these on applying ICT in classroom activities, and did not provide any role modeling specifically related to instructional management.

Although some previous research reported that continuous feedback can promote teachers' ICT competence (Boulton, 2014), our module's integration of instructor and peer feedback was its lowest rated feature, in line with numerous prior results (e.g., Baran et al., 2017; Mouza et al., 2014; Tondeur et al., 2018). This could be taken as an indication that the effective provision of continuous feedback in teacher education contexts remains challenging. However, in our study - as with role modeling - feedback's relatively low ranking may merely suggest that most of the other training strategies were perceived as making even more important contributions.

\section{TPACK}

Before the training module was implemented, many of the participating preservice teachers relied mostly on information carrier tools like mobile devices, and on social media applications that they already felt comfortable with, due to using them on a daily basis (cf. Kessler, 2018). Interestingly, however, it was observed after our training that their ICT use was marked by a willingness to use more interactive, student centered tools. As we reported earlier, participants' overall pretest scores were above the middle, suggesting that they might have already recognized the importance of some of the training's components. Yet, their overall scores on TPACK-practical and on all six of the TPACK-practical subscales still significantly increased after the intervention, implying that the training module and its specific strategies were all perceived positively, and supporting the view that TPACK-practical improves as experience increases (Yeh, Lin, Hsu, Wu, \& Hwang, 2015). The highest scores after training were received by two of the higher order knowledge dimensions - using ICT representations to present materials, and planning ICT infused curricula - which had also been rated highest in the pretest. This implies that the sampled preservice language teachers recognized the importance of integrating technological applications into both curriculum design and teaching practice: a finding also reflected in their answers regarding which ICT tools they used.

\section{Technology adoption}

Today's language teachers feel confident about using technology generally, but unconfident about designing technology supported learning materials and curricula (Jeong 2017; Kessler, 2018). Therefore, language teacher education programs should emphasize how technology can and should be integrated with content, methods, and pedagogy (e.g., Lin et al., 2017; Baser et al., 2016; Bustamante \& Moeller, 2013). In this study, preservice Chinese language teachers mostly rated themselves highly on various 
aspects of technology adoption (i.e., SU, PU and IU), and felt it was easy to use technology (EU); and after training, their scores for all four of these measures increased.

Kessler (2007) demonstrated that one's attitude toward using technology in teaching is an indicator of one's ability to do so; and argued that more preparation for computer-assisted language learning (CALL) in teacher training programs would increase the positivity of such attitudes. Some subsequent studies, conducted in a variety of language contexts, have also shown that incorporating CALL into language education modules within teacher training programs can help preservice teachers adopt technology effectively in their subsequent teaching (e.g., Jeong 2017). The fact that the strategy of learning technology by design had a positive impact on our participants' intentions to use ICT echoed prior findings that, as such teachers experience more, deeper training, the more prominent the effects of specific training strategies will be (Angeli \& Valanides, 2009; Tondeur et al., 2018).

\section{Conclusions}

The results of our pretest and posttest, arrived at using a self report instrument adapted from Tondeur et al. (2016), showed that the participants responded positively to the ICT module, increased their perceived TPACK, and improved their attitudes toward technology, but did not significantly increase their intention to use technology.

Several limitations of the present research should be noted. First, subjective measures were used evaluate the program, albeit with some open ended questions; and given that trainees had not yet started their teaching careers at the time of the posttest, their technology use behaviors during their subsequent teaching careers could not be observed. Second, although the target teacher training program had a comparatively large enrollment by Hong Kong standards, the sample was still small. Lastly, the participating preservice teachers were engaged in ICT training for only 4 weeks, and it is possible that the results would have differed if training had been longer.

Several possible ways of implementing our model in teacher education, and various directions for future research, are also worth mentioning here. First, regarding implementation, the design of role modeling and feedback should be carefully planned and carried out through more explicit presentations. Role models should be presented for more different aspects of teaching with ICT, including preparation of materials, content delivery, activity design, and class management. And, in addition to receiving feedback provided by the instructor, preservice teachers should be given opportunities to examine rubrics for ICT application in language classrooms, and be allowed to serve as feedback providers to their peer groups.

Second, regarding research, longitudinal studies would be useful in assessing the relationships between and among preservice language teachers' perceptions of their ICT training, their actual use of technology, their pedagogical beliefs, and their technology self-efficacy. Additionally, research on a guiding framework of consequential transition - i.e., a belief that deep, difficult and penetrating reflection will result in critical changes (Chao, 2015) - could help to disentangle the reasons that language teachers use technology, or choose not to, after receiving CALL training. It might also be helpful to look beyond preservice teacher education, by examining the outcomes of applications of the SQD-model to professional development for in-service teachers. And, while the current research only examined the core strategies proposed by the SQD-model, future studies 
could usefully investigate its other key factors (e.g., collaboration across institutions and shared visions of teacher development), especially in light of some scholars' arguments that teacher training programs should collaborate to identify the best training strategies and models (e.g., Lee \& Lee, 2014). Finally, recent studies have suggested that pedagogical beliefs are key predictors of teachers' technology adoption (e.g., Liu et al., 2017); yet, the question of whether training can shape preservice teachers' pedagogical beliefs - and thus, such adoption - remains unanswered. Exploring this topic could helpfully expand the role played by pedagogical belief in the technology acceptance model and/ or similar models.

\section{Acknowledgements}

This research was made possible by the Hong Kong Polytechnic University's Faculty of Humanities International Collaboration project: 1-ZVKX Conversational Brains: A Multidisciplinary Approach.

\section{Authors' contributions}

Both Yu-Yin Hsu and Chin-Hsi Lin have made substantial contributions to the conceptualization, methodology, and the design of the study. Yu-Yin Hsu has contributed to the data collection, project administration, and funding acquisition. Chin-Hsi Lin has contributed to the formal data analyses. Both Yu-Yin Hsu and Chin-Hsi Lin have worked on the interpretation of data, and the write-up of the manuscript; both have approved the submitted version.

\section{Authors' information}

Dr. Yu-Yin Hsu, Ph.D., is an assistant professor in the Department of Chinese and Bilingual Studies at the Hong Kong Polytechnic University. Her research interests involve linguistics theory, sentence processing, and the pedagogy of teaching Chinese as a second/foreign language. She received her Ph.D. degree from the Department of Linguistics at Indiana University - Bloomington.

Dr. Chin-Hsi Lin, PhD, is an associate professor at the University of Hong Kong. His primary research interests concern emerging technologies in language education. Specifically, his research investigates the learning processes and outcomes associated with online learning in K-12 settings and out-of-school learning contexts. He received his Ph.D. degree from School of Education at the University of California, Irvine.

\section{Funding}

This research was made possible by the Hong Kong Polytechnic University's Faculty of Humanities International Collaboration project 1-ZVKX, Conversational Brains: A Multidisciplinary Approach.

\section{Availability of data and materials}

The full list of items in the pretest and the posttest is available at https://polyu.hk/OojsO.

\section{Ethics approval and consent to participate}

The entire study was approved by, and conducted in accordance with, the ethical guidelines of the research review board of the Hong Kong Polytechnic University prior to the beginning of data collection (HSEARS20170926001). All participants received an explanation of the study and its procedures, and gave their informed consent prior to its commencement. Each received extra course credits as an incentive to participate the study.

\section{Competing interests}

Both the first author Yu-Yin Hsu and the corresponding author Chin-Hsi Lin have NO affiliation or involvement in any organization or entity with any financial interest (such as honoraria; educational grants; participation in speakers' bureaus; membership, employment, consultancies, stock ownership, or other equity interest; and expert testimony or patent-licensing arrangements), or non-financial interest (such as political, personal, religious, ideological, academic, and intellectual competing interests) in the subject matter or materials discussed in this manuscript.

\section{Author details}

${ }^{1}$ The Hong Kong Polytechnic University, CF709, 11 Yuk Choi Rd, Hung Hom, Hong Kong. ${ }^{2}$ The University of Hong Kong, Room 615, Meng Wah Building, Pokfulam Road, Pokfulam, Hong Kong.

Received: 14 January 2020 Accepted: 15 April 2020

Published online: 15 July 2020

\section{References}

Angeli, C., \& Valanides, N. (2009). Epistemological and methodological issues for the conceptualization, development, and assessment of ICT-TPCK: Advances in technological pedagogical content knowledge (TPCK). Computers \& Education, 52, 154-168. https://doi.org/10.1016/j.compedu.2008.07.006.

Angus, K. B. (2017). Learning "about" and learning "through" technology: An analysis of syllabi from foreign language teaching methods courses. CALICO Journal, 34(3), 317-335. https://doi.org/10.1558/cj.26850.

Baran, E., Canbazoglu Bilici, S., Albayrak Sari, A., \& Tondeur, J. (2017). Investigating the impact of teacher education strategies on preservice teachers' TPACK. British Journal of Educational Technology. https://doi.org/10.1111/bjet.12565. 
Baser, D., Kopcha, T. J., \& Ozden, M. Y. (2016). Developing a technological pedagogical content knowledge (TPACK) assessment for preservice teachers learning to teach English as a foreign language. Computer Assisted Language Learning, 29(4), 749-764. https://doi.org/10.1080/09588221.2015.1047456.

Boulton, H. (2014). ePortfolios beyond pre-service teacher education: A new dawn? European Journal of Teacher Education, 37(3), 374-389. https://doi.org/10.1080/02619768.2013.870994.

Braun, V., \& Clarke, V. (2006). Using thematic analysis in psychology. Qualitative Research in Psychology, 3(2), 77-101. https:// doi.org/10.1191/1478088706qp0630a.

Bustamante, C., \& Moeller, A. J. (2013). The convergence of content, pedagogy, and technology in online professional development for teachers of German: An intrinsic case study. CALICO Journal, 30(1), 82-104 Retrieved from http://www. jstor.org/stable/calicojournal.30.1.82.

Chao, C.-C. (2015). Rethinking transfer: Learning from CALL teacher education as consequential transition. Language Learning \& Technology, 19(1), 102-118 10125/44404.

Cheng, H.J. (2014). The study of CSL online teacher training course and the teachers' development of technological pedagogical content knowledge. Journal of Technology and Chinese Language Teaching, 5(2), 1-18 Retrieved from http:// www.tclt.us/journal/2014v5n2/cheng.pdf.

Cheng, H.-J. (2017). A TL-TPACK model on CSL pre-service teachers' competencies of online instruction. In C.-H. Lin, D. Zhang, \& B. Zheng (Eds.), Preparing foreign language teachers for next-generation education, (pp. 198-225). Hershey: IGI Global.

Dorner, H., \& Kumar, S. (2016). Online collaborative mentoring for technology integration in pre-service teacher education. TechTrends, 60(1), 48-55. https://doi.org/10.1007/s11528-015-00161.

European Commission (2013). Survey of schools: ICT in education. In Benchmarking access, use and attitudes to technology in European schools. Brussels: European Commission.

Fraillon, J., Ainley, J., Schulz, W., Friedman, T., \& Gebhardt, E. (2014). Preparing for life in a digital age: The IEA international computer and information literacy study international report. Melbourne: Australian Council for Educational Research (ACER).

Haydn, T. A., \& Barton, R. (2007). Common needs and different agendas: How trainee teachers make progress in their ability to use ICT in subject teaching. Some lessons from the UK. Computers \& Education, 49, 1018-1036. https://doi.org/10.1016/ j.compedu.2005.12.006.

Hong, K. H. (2010). CALL teacher education as an impetus for L2 teachers in integrating technology. ReCALL, 22, 53-69. https://doi.org/10.1017/5095834400999019X.

Hong Kong Education Bureau (2014). Consultation document on the fourth strategy on information technology in education: Realising it potential, unleashing learning power, a holistic approach. Hong Kong: Hong Kong Education Bureau.

Hsu, L. (2016). An empirical examination of EFL learners' perceptual learning styles and acceptance of ASR-based computer-assisted pronunciation training. Computer Assisted Language Learning, 29, 881-900. https//doi.org/10.1080/09588221.2015.1069747.

International Society for Technology in Education (ISTE) (2012). ISTE standards teachers Retrieved from http://www.iste.org/ docs/pdfs/20-14_ISTE_Standards-T_PDF.pdf.

Jeong, K-O. (2017). Preparing EFL student teachers with new technologies in the Korean context. Computer Assisted Language Learning, 30, 488-509. https://doi.org/10.1080/09588221.2017.1321554.

Kessler, G. (2007). Formal and informal CALL preparation and teacher attitude toward technology. Computer Assisted Language Learning, 20, 173-188. https://doi.org/10.1080/09588220701331394.

Kessler, G. (2016). Technology standards for language teacher preparation. In F. Farr, \& L. Murray (Eds.), The Routledge handbook of language learning and technology, (pp. 83-96). New York: Routledge, Tayler \& Francis.

Kessler, G. (2018). Technology and the future of language teaching. Foreign Language Annals, 51(1), 205-218. https://doi.org/ 10.1111/flan.12318.

Kim, D. (2011). Incorporating podcasting and blogging into a core task for ESOL teacher candidates. Computers \& Education, 56, 632-641. https://doi.org/10.1016/j.compedu.2010.10.005.

Kissau, S. (2015). Type of instructional delivery and second language teacher candidate performance: Online versus face-toface. Computer Assisted Language Learning, 28, 513-531. https://doi.org/10.1080/09588221.2014.881389.

Koehler, M. J., \& Mishra, P. (2005). Teachers learning technology by design. Journal of Computing in Teacher Education, 21(3), 94-102. https://doi.org/10.1080/10402454.2005.10784518.

Lam, Y. (2000). Technophilia vs. technophobia: A preliminary look at why second-language teachers do or do not use technology in their classrooms. Canadian Modern Language Review/ La Revue Canadienne Des Langues Vivantes, 56(3), 389-421 Retrieved from http://utpjournals.metapress.com/content/r8675348472824q3.

Laronde, G., \& MacLeod, K. (2012). Modeling various teaching methods in a Faculty of Education in science education: Chalk and talk, virtual labs or hovercrafts. Journal of College Teaching \& Learning (TLC), 9(2), 107-114. https://doi.org/10.19030/ tlc.v9i2.6905.

Lee, Y., \& Lee, J. (2014). Enhancing pre-service teachers' self-efficacy beliefs for technology integration through lesson planning practice. Computers \& Education, 73, 121-128. https://doi.org/10.1016/j.compedu.2014.01.001.

Lin, H. (2015). A meta-synthesis of empirical research on the effectiveness of computer-mediated communication (CMC) in SLA. Language Learning \& Technology, 19(2), 85-117 Retrieved from http://lt.msu.edu/issues/june2015/v19n2.pdf.

Lin, C.-H., Liu, H., \& Hu, Y. (2017). Technology and the education of Chinese-language teachers: Where are we now? Journal of Technology and Chinese Language Teaching, 8(1), 1-15.

Liu, H., Lin, C.-H., \& Zhang, D. (2017). Pedagogical beliefs and attitudes toward information and communication technology: A survey of teachers of English as a foreign language in China. Computer Assisted Language Learning, 30, 745-765. https:// doi.org/10.1080/09588221.2017.1347572.

Liu, M.-H. (2017). Mentoring preservice EFL teachers for technology integration: A cloud-based internship project. In C.-H. Lin, D. Zhang, \& B. Zheng (Eds.), Preparing foreign language teachers for next-generation education, (pp. 175-197). Hershey: IGI Global. https://doi.org/10.4018/978-1-5225-0483-2.ch010.

Liu, M.-H., \& Kleinsasser, R. (2015). Exploring EFL teachers' knowledge and competencies: In-service program perspectives. Language Learning \& Technology, 19(1), 119-138 http://dx.doi.org/10125/44405.

Miles, M. B., \& Huberman, A. M. (1994). Qualitative data analysis: An expanded sourcebook, (2nd ed., ). Thousand Oaks: Sage.

Mishra, P., \& Koehler, M. J. (2006). Technological pedagogical content knowledge: A framework for teacher knowledge. Teachers College Record, 108(6), 1017-1054. 
Mouza, C., Karchmer-Klein, R., Nandakumar, R., Ozden, S. Y., \& Hu, L. (2014). Investigating the impact of an integrated approach to the development of preservice teachers' technological pedagogical content knowledge (TPACK). Computers \& Education, 71, 206-221. https://doi.org/10.1016/j.compedu.2013.09.020.

Oxford, R., \& Jung, S. H. (2007). National guidelines for technology integration in TESOL programs: Factors affecting (non) implementation. Preparing and Developing Technology-Proficient L2 Teachers, $23,48$.

Reinders, H., \& Hubbard, P. (2012). CALL and autonomy. Affordances and constraints. In M. Thomas, H. Reinders, \& M. Warschauer (Eds.), Contemporary CALL, (pp. 359-375). New York: Continuum.

Schmid, E. C., \& Hegelheimer, V. (2014). Collaborative research projects in the technology-enhanced language classroom: Preservice and in-service teachers exchange knowledge about technology. ReCALL, 26(3), 315-332. https://doi.org/10.1017/ S0958344014000135

Tai, S.-J. D. (2015). From TPACK-in-action workshops to English classrooms: CALL competencies developed and adopted into classroom teaching. Language Learning \& Technology, 19(1), 139-164 http://dx.doi.org/10125/44406.

Tearle, P., \& Golder, G. (2008). The use of ICT in the teaching and learning of physical education in compulsory education: How do we prepare the workforce of the future? European Journal of Teacher Education, 31(1), 55-72. https://doi.org/10. 1080/02619760701845016.

Teo, T. (2011). Factors influencing teachers' intention to use technology: Model development and test. Computers \& Education, 57, 2432-2440. https://doi.org/10.1016/j.compedu.2011.06.008.

Tondeur, J., Aesaert, K., Prestridge, S., \& Consuegra, E. (2018). A multilevel analysis of what matters in the training of preservice teacher's ICT competencies. Computers \& Education, 122, 32-42. https://doi.org/10.1016/j.compedu.2018.03.002.

Tondeur, J., van Braak, J., Sang, G., Voogt, J., Fisser, P., \& Ottenbreit-Leftwich, A. (2012). Preparing pre-service teachers to integrate technology in education: A synthesis of qualitative evidence. Computers \& Education, 59, 134-144. https://doi. org/10.1016/j.compedu.2011.10.009.

Tondeur, J., van Braak, J., Siddiq, F., \& Scherer, R. (2016). Time for a new approach to prepare future teachers for educational technology use: Its meaning and measurement. Computers \& Education, 94(supplement C), 134-150. https://doi.org/10. 1016/j.compedu.2015.11.009.

VanVoorhis, C. R. W., \& Morgan, B. L. (2007). Understanding power and rules of thumb for determining sample sizes. Tutorials in Quantitative Methods for Psychology, 3(2), 43-50 http://mail.tqmp.org/RegularArticles/vol03-2/p043/p043.pdf.

Yeh, Y. F., Lin, T. C., Hsu, Y. S., Wu, H. K., \& Hwang, F. K. (2015). Science teachers' proficiency levels and patterns of TPACK in a practical context. Journal of Science Education and Technology. https://ink.springer.com/article/10.1007/s10956-014-9523-7.

Yeh, Y.-F., Hsu, Y.-S., Wu, H.-K., Hwang, F.-K., \& Lin, T.-C. (2014). Developing and validating technological pedagogical content knowledge-practical (TPACK-practical) through the Delphi survey technique. British Journal of Educational Technology, 45, 707-722. https://doi.org/10.1111/bjet.12078.

\section{Publisher's Note}

Springer Nature remains neutral with regard to jurisdictional claims in published maps and institutional affiliations.

\section{Submit your manuscript to a SpringerOpen ${ }^{\circ}$ journal and benefit from:}

- Convenient online submission

- Rigorous peer review

- Open access: articles freely available online

High visibility within the field

- Retaining the copyright to your article

Submit your next manuscript at $\boldsymbol{s p r i n g e r o p e n . c o m ~}$ 